\title{
The Comprehensive Consideration on Optimizing the Teaching Mode of Physical Education in Colleges and Universities
}

\author{
Wen Zhou \\ Sports Center \\ Wuhan College \\ Wuhan, P.R.China
}

\begin{abstract}
Physical education in colleges and universities is an important basis for the purpose of cultivating students' allround development of mind and body and lifelong physical training. The establishment of college physical education teaching mode in the new era is the need for high-quality talents in the new era. Based on the analysis of health status of college students, the optimization of college physical education teaching mode has an important influence on the quality of teaching and students' physical and mental health. The thoughts about college sports teaching mode, teaching mode of mental health and the establishment of a new mode of teaching evaluation system provide a useful reference for the optimization of college physical education teaching mode.
\end{abstract}

Keywords-optimization design; teaching mode; colleges and universities

\section{INTRODUCTION}

The Ministry of Education promulgated the "National Ordinary College Sports Curriculum Teaching Instruction Summary" of course put forward the target system including sports participation, sports skills, physical development, mental development and social adaptation of the five areas of learning. The construction of the curriculum goal fundamentally gets rid of the original imprisonment ideology of physical education, and makes the original curriculum objective change from the knowledge technology to the teaching mode which can promote the all-round development of students. How to improve the existing physical education model and break the existing teaching pattern is one of the problems that the current sports teaching is urgent to solve. We should make necessary adjustments and supplements to the existing sports teaching methods so as to adapt to the new requirements of the modern society for school sports.

\section{ANAlysis OF THE HeAlth StAtus of CollegE STUDENTS}

According to the survey, the current health of the university students have a downward trend, mainly for testing indicators of physical quality, such as the body's immune ability, self-exercise ability, learning and participating in school activities of the collective attendance rate and other indicators show a declining trend. According to the physical test of students in universities every year, the trend of physical development of undergraduates shows the following characteristics: firstly, the health status of body shape. As men age, men and women lose weight and malnutrition are not much better, and the proportion of overweight and obesity increases. Second is physical function. With the increase of age, both male and female students' rating levels showed a downward trend, especially the male students' physical function development level was significantly behind the growth level of body shape. Third is physical condition. With the increase of age, the evaluation grade of the index has a downward trend.

The physical quality of college students is decreasing year by year, which should be paid more attention to by the Department of physical education in higher education, and should be considered by front-line sports workers. To carefully analyze the causes for the decrease of students' physical function and quality, to explore more practical teaching mode, teaching mechanism and policy, to inspire and guide students to concern the importance of physical exercise on physical health, and actively participate in physical exercise. The university sports teaching purpose is not only to have a good physique and health promoting students, help students develop aspects of fitness, entertainment, life and so many kinds of physical skills and improve the students' Ideological and moral behavior, and positive attitude toward life, ensure students physical stamina to learn more; it is important for students after graduation can be successfully put into to obtain high quality work life lay the foundation.

\section{THE INFLUENCES OF REFORMING THE MODE OF} PHYSICAL EDUCATION IN COLLEGES AND UNIVERSITIES ON TEACHING AND STUDENTS

The reform of physical education must conform to the direction of social development. With the aim of guiding the teaching of physical education in Colleges and universities in our country, we should aim at the students' physical and mental health, and set up a practical and effective teaching mode. It is necessary to reform the mode of physical education in Colleges and universities, improve the quality 
of physical education and promote the all-round and healthy development of students' mind and body.

\section{A. Teaching Quality}

- Optimize the teaching mode and adopt individualized teaching for different students. Effective teaching methods are adopted to enable students to achieve optimal learning and exercise. In the teaching of physical education "teaching" and "learning", is a two-way interactive process, students can have a decisive effect for improving the quality of teaching, according to different sports and teaching object differences, using different teaching methods and teaching methods.

- Sports theory and practice teaching are closely integrated and mutually promoted. Modern physical education requires teachers to have a good knowledge structure and pursue new knowledge constantly. More importantly, the theory should be applied to practice, to test and improve the theory, and constantly improve the practical application ability of teachers.

- Effective organization of teaching, improve teaching efficiency. Under the limited time, field and equipment condition, teachers can carry out teaching activities in the form of effective design, which puts forward higher requirements for teachers' teaching methods and teaching ability. Teachers should pay attention to the cultivation of students' health awareness and fitness methods, uphold the concept of lifelong education, and fundamentally help students establish a sense of willingness to participate in physical exercise, so that students can reach the best state of mind and body.

\section{B. Students' Mind and Body}

The characteristics of the sports curriculum is different from other indoor sports courses, teachers' classroom emotional investment will directly affect the course of students' interest in learning, teachers use a reasonable method of practice, can be effective to stimulate classroom atmosphere, let students have a great sense of comfort, happiness, beauty, rhythm and rhythm from each a cell in the body in a burst of vitality and vitality of life, stimulate their self-confidence and initiative, good mood form open-minded, cheerful, adapt to the society smoothly, become talents.

\section{THE PONDERING ON UNIVERSITY SPORTS TEACHING MODE}

Teaching mode is the reflection of certain teaching theory, and is a norm of teaching behavior under the guidance of certain theories. Different educational views often put forward different teaching models. Any kind of teaching model is designed around a certain teaching goal, and the effective use of each teaching mode also needs certain conditions. For example, the theoretical basis and concept attainment model is the first organization model of Cognitive Psychology Learning Theory and situational mold mode theory is the conscious mental activity and unconscious mental activity, unity of sense and sensibility in the cognitive activities. In the process of teaching model, we must consider the characteristics of students, the content of teaching, the existing teaching conditions and the specific situation of teachers and students, so as to reflect the active adaptation to the characteristics of subjects. The teaching program of physical exercise mode is to make the students clear the purpose and method of exercise.

\section{A. Teaching Objectives}

We investigate the subjects' gender, physical quality, interest and so on, and understand the subjects of teaching, and make teaching objectives on the basis of diagnosis. If the subject is male, it is necessary to determine the teaching plan according to the boys like confrontational sports, exercise ability, irritability and other characteristics, the girls on the other hand, it's possible to maximize the advantages of the student body, let them realize their value, develop good exercise habits, and gradually formed the idea of lifelong physical exercise.

\section{B. Exercise Objective}

On the basis of diagnosis, teachers should set up exercise plans and learning goals according to the specific conditions of students. Through the understanding of students, a clear set of this semester or all physical education courses, establish a stage to achieve goals or tasks, so that each stage to make a difference, to serve the overall teaching objectives. According to the actual situation of students, teaching plans can be made, so that different learning objects will gain in the process of learning, and play their own potential. For the top students in sports, in teaching content, we should appropriately expand the development of teaching, overcome their lack of food, and ask teachers to help organize other students to practice. For sports students, we should put forward the corresponding teaching requirements according to the curriculum objectives, stimulate interest and develop potential, and strive for closer to the top students. On physical education students, the teaching goal setting should be targeted, individualized, design some easy to practice in the teaching content, to fully mobilize their enthusiasm, allow them to make mistakes, and give more encouragement, guidance and help, the success of pleasure and emotional experience, establish continuous improvement confidence.

\section{Exercise Effect}

In view of the students' physical condition, the students are taught how to choose a project and what kind of exercise they are expected to achieve. Students can choose proper sports according to their hobbies and exercise plans, and teachers should give proper advice and guidance to make them more effective. Most universities in China adopt the way of students' independent choice, such as, according to the number of sports, the project can be roughly divided into collective and individual projects. Basketball, football, volleyball and other ball games belong to collective projects, with collective cooperation as the premise, there must be a clear division of labor and strong antagonism. Martial arts, 
tennis, badminton, aerobics, table tennis and other individual items, higher technical requirements of their own, there is no direct physical contact confrontation. The characteristics of the project itself are different, and the mode of movement and the effect of the movement are different.

\section{Optimizing Exercises}

First of all, let the students master the technical movements and key points, and then organize the students to practice again and again to promote the students to set up the consciousness of conscious practice. Teach students how to find problems, analyze problems, and validate theories. According to the characteristics of the project organization of students, such as a group project to organize students to improve their ability in the foundation, to carry out collaborative practice; individual project to break the limitation of the original project, part of the students before class a group of strong games. Combine the different teaching objects; choose the suitable exercise practice method.

\section{E. Strengthening Safety Education}

With the development of society, the social environment has put forward more requirements for human living conditions. Most college graduates go to the society and live independently, facing various social phenomena. Self preservation is our basic survival skill. But for a long time, safety education is only "slogan", and has not been effectively implemented. According to the characteristics of education and physical education item itself to protect the safety of skill specific requirements, we can use the skill courses and specialized physical form, safety education and physical education will effectively link in each semester arrangement theory courses and practice courses, such as the female self-defense, escape exercises and self-protection law, and always will be safe throughout all aspects of education and implementation.

\section{Thoughts about the Teaching Mode of PSYCHOLOGICAL HEALTH IN COLLEGES AND UNIVERSITIES}

Physical education is an important means to find and eliminate the psychological obstacles of college students. Physical education is the process of imparting knowledge, skills and skills, including the pleasurable experience of emotional success. Students in the course of learning and physical activities in the process of behavior, expression, will be reflected in the performance of their psychological state of the true reflection, through observation, it is easy to find that students have varying degrees of psychological barriers. Exercise can slow down and cure certain mental disorders, diseases, and stress, stress, anxiety, depression, and other negative emotions that can make people feel happy and relaxed. Restriction of school physical education curriculum teaching by the teaching goal, most of the sports skills teaching mode, exercise teaching mode, improving teaching content ignored the students' mental health, evaluation methods of quantitative evaluation and summative assessment form on motor skill scores as the only evaluation criteria, without considering the physical quality of students and learning, emotional attitude. The guiding ideology of teaching mode based on these and embodied, not to cultivate the students' psychological adjustment ability as the goal, not paying attention to the students' psychological adjustment ability, psychological quality and psychological health level, the lack of teaching arrangement can improve students' mental health teaching means, teaching methods and curriculum.

\section{A. Establishing the Student Body and Mind Health File through the Psychological Consultation Room and the Network Resources}

Rely on the advantage of network teaching resources integration, physical and mental health records established counseling rooms and students every year, a mental health questionnaire for students to master the psychological changes, students in the school for four years, and set up psychological counseling for students to solve the students, "fear" and "shame" and other psychological disorders and status did not dare to medical treatment.

\section{B. Setting up Teaching Situation and Optimizing Classroom Teaching Mode}

How to cultivate students' positive and healthy mental attitude and adapt to social ability has become a problem for the general physical education workers. Each semester teaching arrangements for a certain class of situational teaching, cultivate students' team spirit and ability to deal with emergencies, such as camping, simulated solution bracelet, Yun Chi ball and other activities, students through teamwork in specific contexts to complete certain learning objectives, through the activities to make students feel a lot of things to the team joint efforts to achieve the goal. At the same time, the teacher's guidance and summary will also have great educational effect. The teaching situation is set up, the exchange of ideas between teachers and students, which can help students find their own usually are not aware of the lack, blind spots and potential, so that they experience a strong sense of achievement and personal struggle of the collective combat pleasure, this has the positive transfer effect on the students' future work and learning, students will be more active attitude to life on the road of life. With the mode of outward bound, it can supplement and extend the content and function of physical education, and the development space is very large, which meets the requirements of the current health goals.

\section{Strengthening the Mental Health Education of Students, and Combining Teaching Content with Abundant Teaching Means}

Every year, students are organized to watch mental health knowledge films and invite experts to hold lectures on mental health knowledge. Students are encouraged to participate actively in the form of questions and answers in the form of mental health knowledge so as to achieve the effect of knowledge serving themselves. In the teaching process, we can use a variety of lively, diverse forms of teaching methods to stimulate students' interest in learning, so that students can experience happiness in sports teaching 
and fall in love with physical education. The students with obsessive-compulsive disorder and depression can play a better role in relieving and regulating. In the course of teaching, teachers should participate in sports activities with students as much as possible, and create new and harmonious relationship between teachers and students, so that students can fully trust PE teachers and be willing to communicate with teachers. Consciously make students communicate with each other, help each other, to create a harmonious interpersonal relationship and good teaching atmosphere, has a good effect on the treatment of students' bad psychological. In addition to the teachers inspire and encourage students' confidence, can also choose representative students to do exercises, technical exercises when they finished successfully, can quickly eliminate psychological concerns, enhance their confidence to complete the action. Teachers should set up certain difficulties, and train students' will quality with purpose and plan.

\section{The Establishment of A NeW TEACHING Model EVALUATION SYSTEM}

Sports teaching evaluation should weaken the function of screening and selection of evaluation, and establish a new educational evaluation system with diverse contents and various ways of evaluation, so as to promote the development of students and the quality of teachers. Teaching evaluation content mainly includes the following: the expert level of acceptance of the teaching mode, students must degree of teaching mode, students' level of acceptance of learning contents and training methods, students through the implementation of the teaching mode of physical and mental health changes, evaluation of humanity because of the individual differences have different effects. To evaluate the teaching effect of students teaching mode and physical exercise, not only has important significance for improving students' physical quality and cultivate a strong will, but also to promote the development of students' mental health from. The model should be constantly improved and surpassed in practical application so as to maximize its teaching effect.

\section{CONCLUSION}

Investigation and research show that teachers should pay attention to the renewal of teaching mode in the course of teaching, and pay attention to students' psychological adjustment ability, psychological quality and mental health level according to the characteristics of teaching objects. According to the teaching object design practical and effective teaching mode, so that the model can effectively adjust the students' psychological conflict and reducing students' psychological pressure and improve the mental health of students, improve students' psychological quality. Cultivate the students' subjective consciousness, explore and practice the spirit actively, and give full play to the positive influence of the students' personality. In a word, the reform and optimization of college physical education mode play an important role in promoting the all-round development of physical and mental development of college students, and cultivating modern talents with good physique, good posture and elegant quality.

\section{REFERENCES}

[1] Fan Aiwu, Li Yingchun. The Influences of University PE and Health Education on the Body and Mind Health of College Students [J]. Journal of Harbin Institute of Physical Education, 2003(4).

[2] Cao Liang, Zhu Jun. The Tutorial Effect of University Physical Education on Psychological Health of College Students[J]. Journal of Tianjin Manager College, 2008(3).

[3] Pan Yuehua, Li Yansong. The Influence and Function of University Physical Education on Psychological Health of College Students[J]. Education Exploration, 2008(7).

[4] Lu Gang. The Effect of Physical Education on Psychological Health Education of College Students[J]. Journal of Beijing Vocational \& Technical Institute of Industry, 2007(1) 